\title{
Pesticide residues in crops produced in the north-eastern Poland (2013)
}

\author{
Pozostałości środków ochrony roślin w płodach rolnych \\ wyprodukowanych w północno-wschodniej Polsce (2013)
}

\author{
Bożena Łozowicka, Izabela Hrynko, Ewa Rutkowska, Magdalena Jankowska, Piotr Kaczyński
}

\begin{abstract}
Summary
This paper presents results of official control of pesticide residues in the crops from the north-eastern Poland. In total 260 samples were analysed in the year 2013 (45\% fruit, 44.2\% vegetables and 10.8\% cereals and oilseeds). Among 188 pesticides, 36 active substances were detected, including $57.3 \%$ fungicides. Pesticide residues most often were determined in the samples of fruit (74.4\%), mainly in currants (28.2\%) and apples (25.6\%). Pesticide residues below the maximum residue levels (MRLs), contained $45.4 \%$ (118) samples, while $5.4 \%$ (14) of tested sample exceeding MRLs. The use of non-approved pesticides was stated in $5 \%$ of tested samples. In 2013, 17 reports within the Rapid Alert System for Food and Feed (RASFF) were issued.
\end{abstract}

Key words: crops; pesticide residues; north-eastern Poland; RASFF notifications

\section{Streszczenie}

Celem opracowania była analiza wyników kontroli urzędowej pozostałości środków ochrony roślin (ś.o.r.) w płodach rolnych z północno-wschodniej Polski. W 2013 roku przeprowadzono badania 260 próbek (45\% owoców, 44,2\% warzyw i 10,8\% zbóż i roślin oleistych). Spośród 188 oznaczanych pestycydów wykryto 36 substancji czynnych (s.cz.), w tym 57,3\% fungicydów. Pozostałości ś.o.r. najczęściej oznaczono w próbkach owoców (74,4\%), głównie w porzeczkach $(28,2 \%)$ i jabłkach $(25,6 \%)$. W 45,4\% (118) próbek stwierdzono pozostałości poniżej najwyższych dopuszczalnych poziomów (NDP), a w 5,4\% (14) próbek powyżej NDP. W 5\% ogółu odnotowano obecność s.cz. niedozwolonych do stosowania. W 2013 roku wystawiono 17 powiadomień w ramach Systemu Wczesnego Ostrzegania o Niebezpiecznej Żywności i Paszach (Rapid Alert System for Food and Feed - RASFF).

Słowa kluczowe: płody rolne; pozostałości pestycydów; północno-wschodnia Polska; powiadomienia informacyjne RASFF

\footnotetext{
Instytut Ochrony Roślin - Państwowy Instytut Badawczy

Terenowa Stacja Doświadczalna

Laboratorium Badania Pozostałości Środków Ochrony Roślin

Chełmońskiego 22, 15-195 Białystok
}

B.Lozowicka@iorpib.poznan.pl; biuro@ior.bialystok.pl 


\section{Wstęp / Introduction}

Bezpieczeństwo zdrowotne konsumentów powinno być zapewnione przez dostępność na rynku płodów rolnych wolnych od pozostałości środków ochrony roślin (ś.o.r.). Stosowanie chemicznych preparatów stanowi najpowszechniej wykorzystywaną metodę ochrony roślin przed chorobami, szkodnikami i chwastami. Jednak nieprawidłowe lub nadmierne ich stosowanie w rolnictwie niesie za sobą liczne niebezpieczeństwa, powodujące m.in. występowanie pozostałości ś.o.r. w płodach rolnych w ilościach zagrażających zdrowiu konsumentów. Zminimalizowaniu tego ryzyka służą rygorystyczne wymagania dotyczące rejestracji środków, jak również systematyczna kontrola ich pozostałości w żywności.

Laboratorium Badania Pozostałości Środków Ochrony Roślin (LBPŚOR) w Białymstoku prowadzi badania pozostałości ś.o.r. akredytowanymi metodami w płodach rolnych w ramach kontroli urzędowej wykonywanej na zlecenie Głównego Inspektoratu Ochrony Roślin i Nasiennictwa (GIORiN). Obecnie realizowana jest ona w ramach Programu Wieloletniego „Ochrona roślin uprawnych z uwzględnieniem bezpieczeństwa żywności oraz ograniczenia strat $\mathrm{w}$ plonach i zagrożeń dla zdrowia ludzi, zwierząt domowych i środowiska" w latach 2011-2015.
Celem opracowania jest analiza wyników kontroli urzędowej pozostałości ś.o.r. w płodach rolnych z północno-wschodniej Polski w 2013 roku. Uzyskane wyniki stanowią ważną informację dla konsumentów żywności oraz decydentów politycznych o jakości produktów rolnych pozyskiwanych z rejonów Polski uznawanych za ekologiczne. Gwałtowny wzrost produktów rolnych zawierających pozostałości ś.o.r. jest niepokojący i powinien być sygnałem do podjęcia działań służb rolniczych w tym zakresie.

\section{Materiały i metody / Materials and methods}

Materiał do badań stanowiło 260 próbek, w tym 117 owoców (45\%), 115 warzyw (44,2\%) i 28 zbóż i roślin oleistych $(10,8 \%)$. Próbki pobrane losowo przez inspektorów Wojewódzkich Inspektoratów Ochrony Roślin i Nasiennictwa (WIORiN) zgodnie z programem kontroli urzędowej, zróżnicowanym dla poszczególnych upraw, pochodziły z 3 województw północno-wschodniej Polski: lubelskiego - 119 (45,8\%), warmińsko-mazurskiego - 71 $(27,3 \%)$ i podlaskiego - 70 próbek $(26,9 \%)$. W badaniach analitycznych poszukiwano pozostałości 188 substancji czynnych (s.cz.) ś.o.r.: 84 insektycydów i akarycydów, 75 fungicydów oraz 29 herbicydów i regulatorów wzrostu (tab. 1).

Tabela 1. Analizowane substancje czynne ś.o.r. i ich granice oznaczalności [mg/kg]

Table 1. Analysed active substances and their limits of determination $[\mathrm{mg} / \mathrm{kg}]$

\begin{tabular}{|c|c|}
\hline 1 & 2 \\
\hline $\begin{array}{l}\text { Insektycydy } \\
\text { i akarycydy } \\
\text { Insecticides } \\
\text { and acaricides } \\
\text { (84) }\end{array}$ & 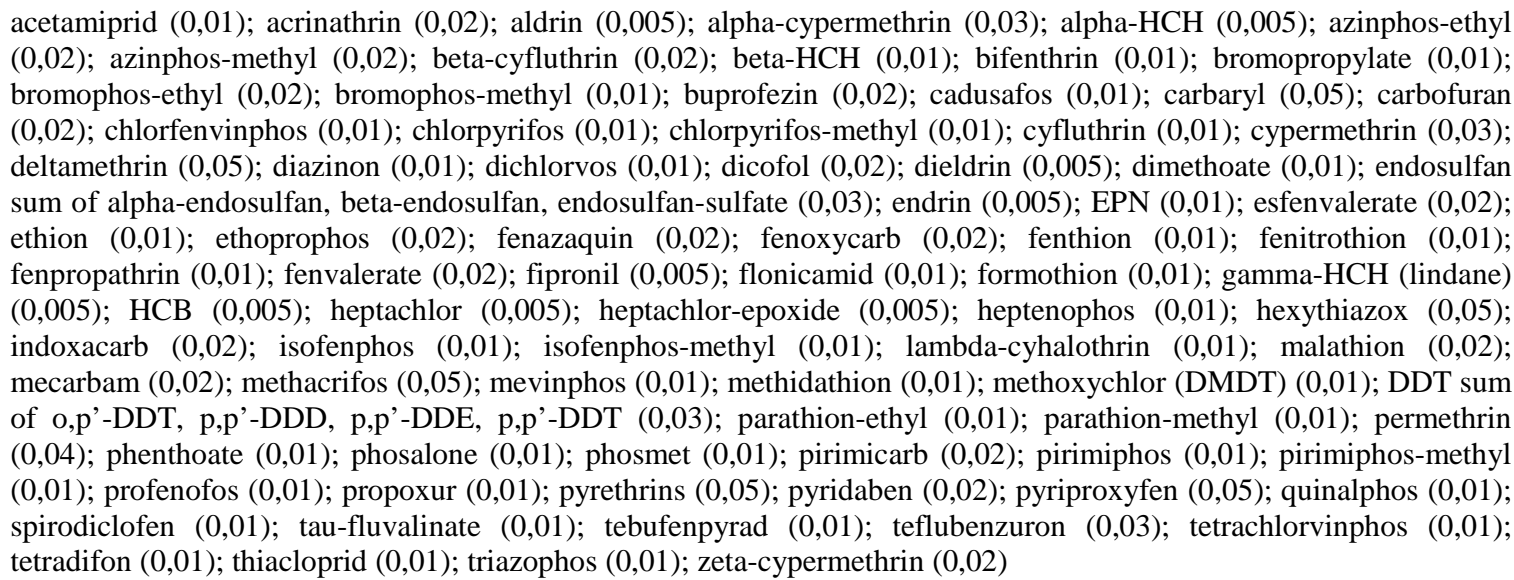 \\
\hline
\end{tabular}

azaconazole $(0,01)$; azoxystrobin $(0,02)$; benalaxyl $(0,03)$; bitertanol $(0,013)$; boscalid $(0,01)$; bromuconazole $(0,01)$; bupirimate $(0,01)$; captafol $(0,02)$; captan $(0,01)$; carbendazim $(0,02)$; chlorothalonil $(0,01)$; chlozolinate $(0,01)$; cyproconazole $(0,01)$; cyprodinil $(0,01)$; dichlofluanid $(0,01)$; dicloran $(0,01)$; difenoconazole $(0,05)$; dimethomorph $(0,05)$; dimoxystrobin $(0,01)$; diniconazole $(0,01)$; diphenylamine $(0,01)$; dithiocarbamates* $(0,05)$; epoxiconazole $(0,01)$; etaconazole $(0,01)$; famoxadone $(0,02)$; fenarimol $(0,01)$; fenbuconazole $(0,01)$; fenchlorphos $(0,01)$;

Fungicydy Fungicides (75) fenhexamid $(0,01)$; fenpropimorph $(0,02)$; fludioxonil $(0,01)$; fluquinconazole $(0,01)$; fluopicolide $(0,01)$; flusilazole $(0,01)$; flutolanil $(0,02)$; flutriafol $(0,01)$; hexaconazole $(0,01)$; folpet $(0,01)$; imazalil $(0,01)$; imibenconazole $(0,01)$; iprodione $(0,02)$; iprovalicarb $(0,03)$; isoprothiolane $(0,01)$; kresoxim-methyl $(0,01)$; mepanipyrim $(0,01)$; metalaxyl $(0,01)$; metconazole $(0,01)$; metrafenone $(0,01)$; myclobutanil $(0,01)$; oxadixyl $(0,03)$; paclobutrazol $(0,02)$; penconazole $(0,02)$; pencycuron $(0,03)$; picoxystrobin $(0,01)$; prochloraz $(0,01)$; procymidone $(0,01)$; propiconazole $(0,01)$; prothioconazole-desthio $(0,02)$; pyrazophos $(0,01)$; pyrimethanil $(0,01)$; quinoxyfen $(0,01)$; quintozene $(0,01)$; tebuconazole $(0,01)$; tecnazene $(0,02)$; tefluthrin $(0,01)$; tetraconazole $(0,01)$; thiabendazole $(0,03)$; tolclofos-methyl $(0,01)$; tolylfluanid $(0,02)$; triadimefon $(0,02)$; triadimenol $(0,05)$; trifloxystrobin $(0,01)$; triticonazole $(0,01)$; vinclozolin $(0,01)$; zoxamide $(0,02)$ 


\begin{tabular}{|c|c|}
\hline 1 & 2 \\
\hline $\begin{array}{l}\text { Herbicydy } \\
\text { i regulatory } \\
\text { wzrostu } \\
\text { Herbicides } \\
\text { and growth } \\
\text { regulators } \\
\text { (29) }\end{array}$ & $\begin{array}{l}\text { acetochlor }(0,02) \text {; atrazine }(0,01) \text {; bromacil }(0,01) \text {; chloridazon }(0,01) \text {; chlorpropham }(0,01) \text {; cyanazine }(0,01) \text {; } \\
\text { cyprazine }(0,01) \text {; diflufenican (DFF) }(0,01) \text {; flurochloridone }(0,01) \text {; lenacil }(0,02) \text {; linuron }(0,02) \text {; metazachlor }(0,01) \text {; } \\
\text { metholachlor }(0,02) \text {; metribuzin }(0,02) \text {; napropamide }(0,02) \text {; nitrofen }(0,01) \text {; oxyfluorfen }(0,01) \text {; pendimethalin }(0,02) \text {; } \text {; } \text {; } \text { procyazine }(0,01) \text {; prometryn }(0,01) \text {; propachlor }(0,02) \text {; propaquizafop }(0,03) \text {; propazine }(0,01) \text {; propham }(0,02) \text {; } \\
\text { propyzamide }(0,02) \text {; simazine }(0,01) \text {; terbuthylazine }(0,01) \text {; terbutryn }(0,01) \text {; trifluralin }(0,01)\end{array}$ \\
\hline
\end{tabular}

*oznaczane jako pozostałości $\mathrm{CS}_{2}$ - determined as $\mathrm{CS}_{2}$ residues

$\mathrm{W}$ nawiasach podano granice oznaczalnosci w $\mathrm{mg} / \mathrm{kg}$ - The limits of determination were given in brackets in $\mathrm{mg} / \mathrm{kg}$

Stosowano akredytowane metody oznaczania pojedynczych związków (ditiokarbaminianów, karbendazymu i linuronu) oraz multimetody analityczne umożliwiające analizę wielu związków jednocześnie, spełniające wymagania przewodnika SANCO (SANCO 2011). Jakościowe i ilościowe oznaczenia pozostałości wykonano techniką chromatografii gazowej (GC - gas chromatography) z wykorzystaniem dwóch detektorów selektywnych: EC (electron capture - wychwytu elektronów) i NP (nitrogen phosphorus - azotowo-fosforowy) (Łozowicka 2010) oraz wysokosprawnej chromatografii cieczowej (HPLC - High Performance Liquid Chromatography) w dualnym systemie detekcji (Łozowicka i Kaczyński 2009). Pozostałości ditiokarbaminianów, wyrażone jako $\mathrm{CS}_{2}$ oznaczano spektrofotometrycznie (Chmiel 1979).

Poprawność metod sprawdzano systematycznie poprzez udział w międzynarodowych badaniach biegłości (PT - Proficiency Test) organizowanych przez Unię Europejską (European Commission's Proficiency Tests on Pesticide Residues in Fruit and Vegetables in Spain as well as in Cereals and Feeding Stuff in Denmark) oraz Zakład Badania Pozostałości Środków Ochrony Roślin Instytutu Ochrony Roślin - Państwowego Instytutu Badawczego w Poznaniu. Analogicznie do lat ubiegłych, w omawianym okresie badawczym Laboratorium uzyskało poprawne wyniki, co dowodzi, iż system kontroli poziomu pozostałości jest prawidłowy i zapewnia uzyskiwanie rzetelnych wyników badań.

Oznaczone stężenia s.cz. porównano z najwyższymi dopuszczalnymi poziomami pozostałości (NDP) obowiązującymi w Polsce i Unii Europejskiej (Rozporządzenie WE 2005). Przekroczenia dopuszczalnych poziomów pozostałości oceniano, uwzględniając 50\% niepewność pomiaru, zgodnie z dokumentem ,Method validation and quality control procedures for pesticide residues analysis in food and feed" (SANCO 2011). Przypadki przekroczeń NDP oraz stosowania niezalecanych ś.o.r. w danej uprawie (Ustawa 2004) były niezwłocznie zgłaszane w ramach europejskiego systemu Rapid Alert System for Food and Feed (RASFF) (Ustawa 2006).

W przypadku produktów, w których stwierdzono przekroczenie NDP oszacowano narażenie krótkoterminowe poprzez porównanie jednorazowego lub jednodniowego pobrania wykrytej najwyższej pozostałości ś.o.r. w danym produkcie do ustalonej wielkości ostrej dawki referencyjnej (Acute Reference Dose - ARfD). Ocenę ryzyka narażenia zdrowia związanego ze spożyciem płodów rolnych zawierających pozostałości ś.o.r. dokonano w oparciu o dostępne badania epidemiologiczne, przeprowadzone dla najbardziej krytycznej subpopulacji (dzieci w wieku 1,5-4 lat). Ze względu na brak pełnych danych dla tej grupy wiekowej w Polsce, informacje dotyczące pobrania pozostałości poprzez dietę zaczerpnięto $\mathrm{z}$ brytyjskiego modelu stosowanego przez Urząd Bezpieczeństwa Pestycydów Ministerstwa ds. Środowiska Żywności i Rolnictwa (PSD 2006).

\section{Wyniki i dyskusja / Results and discussion}

Ponad połowa próbek $(132 ; 50,8 \%)$ zawierała pozostałości ś.o.r. Wolnych od pozostałości było 49,2\% próbek, w tym 25,6\% owoców, 62,6\% warzyw oraz 92,9\% zbóż i roślin oleistych. Szczegółowe dane zakresu wykrytych stężeń i rodzajów pestycydów w płodach rolnych przedstawiono w tabeli 2 .

Pozostałości wykrywano najczęściej w próbkach owoców - 74,4\%, o połowę mniej stwierdzono ich w warzywach - 37,4\%, a tylko $7,1 \%$ w zbożach i roślinach oleistych. Najwyższy odsetek próbek zanieczyszczonych stanowiły porzeczki (86,8\% wszystkich próbek porzeczek) oraz jabłka (71,4\% wszystkich próbek jabłek). Dla porównania według Nowackiej (2013) w krajowym monitoringu żywności $56,7 \%$ jabłek oraz $51,6 \%$ porzeczek zawierało pozostałości ś.o.r.

Spośród 34 badanych asortymentów płodów rolnych w 15 owocach, warzywach, zbożach i roślinach oleistych pozostałości ś.o.r. nie wykryto.

Ze 188 pestycydów objętych programem badań oznaczono 36 s.cz. (19,1\%). Najczęściej wykrywano pozostałości fungicydów, $\mathrm{z}$ czego najpowszechniej ditiokarbaminiany $(32,3 \%)$. Wyniki te korelują $\mathrm{z}$ wynikami otrzymanymi przez Szpyrkę i wsp. (2013) w 2012 roku na terenie Polski południowo-wschodniej. Wśród insektycydów najczęściej oznaczano tiaklopryd (20,5\%).

Spośród próbek zawierających pozostałości ś.o.r. przeważający odsetek stanowiły takie, w których oznaczono jeden (52 próbki) oraz dwa związki (44 próbki). Trzy s.cz. stwierdzono w 17 próbkach, cztery s.cz. wystąpiły w 9 próbkach, pięć s.cz. oznaczono w 3 próbkach, natomiast sześć s.cz. wystąpiło w 7 próbkach (w 6 próbkach porzeczek oraz w 1 próbce jabłek). Szczegółowe dane o poziomach pozostałości ś.o.r. zamieszczone zostały w tabeli 2. Dla porównania w 2012 roku w Polsce północno-wschodniej dwie s.cz. stwierdzono w 4 próbkach, trzy s.cz. wystąpiły w 3 próbkach, cztery s.cz. oznaczono w 2 próbkach, natomiast próbek zawierających więcej pozostałości nie stwierdzono (Łozowicka i wsp. 2013). 
Tabela 2. Wykryte pozostałości ś.o.r. w płodach rolnych

Table 2. Pesticide residues detected in the crops

\begin{tabular}{|c|c|c|c|c|c|c|c|}
\hline \multirow{3}{*}{$\begin{array}{l}\text { Produkt** } \\
\text { Product }\end{array}$} & \multirow{3}{*}{$\begin{array}{c}\text { Liczba próbek } \\
\text { (\% próbek) } \\
\text { Number } \\
\text { of samples } \\
\text { (percentage } \\
\text { of samples) }\end{array}$} & \multirow{3}{*}{$\begin{array}{l}\text { Substancja czynna } \\
\text { Active substance }\end{array}$} & \multicolumn{2}{|c|}{$\begin{array}{c}\text { Próbki } \\
\text { z pozostalościami } \\
\text { Samples with residues }\end{array}$} & \multirow{2}{*}{\multicolumn{2}{|c|}{$\begin{array}{c}\text { Zakres wykrytych } \\
\text { pozostałości } \\
\text { Range of detected residues } \\
{[\mathrm{mg} / \mathrm{kg}]}\end{array}$}} & \\
\hline & & & \multirow{2}{*}{$\begin{array}{l}\text { liczba } \\
\text { number }\end{array}$} & \multirow{2}{*}[\%]{} & & & \\
\hline & & & & & $\min$. & $\max$ & \\
\hline 1 & 2 & 3 & 4 & 5 & 6 & 7 & $\begin{array}{c}\begin{array}{c}\mathrm{NDP} * \\
\mathrm{MRL} \\
{[\mathrm{mg} / \mathrm{kg}]}\end{array} \\
8\end{array}$ \\
\hline $\begin{array}{l}\text { Agrest } \\
\text { Gooseberry }\end{array}$ & $\begin{array}{c}1 \\
(0,4)\end{array}$ & $\begin{array}{c}\text { bupirimate } \\
\text { dithiocarbamates } \\
\text { difenoconazole } \\
\end{array}$ & $\begin{array}{l}1 \\
1 \\
1 \\
\end{array}$ & $\begin{array}{l}100 \\
100 \\
100 \\
\end{array}$ & $\begin{array}{l}0,820 \\
0,250 \\
0,270^{1,2}\end{array}$ & $\begin{array}{l}- \\
- \\
-\end{array}$ & $\begin{array}{c}5 \\
5 \\
0,1 \\
\end{array}$ \\
\hline $\begin{array}{l}\text { Buraki cukrowe } \\
\text { Sugar beet }\end{array}$ & $\begin{array}{c}2 \\
(0,8) \\
\end{array}$ & beta-cyfluthrin & 1 & 50 & 0,060 & - & 0,5 \\
\hline $\begin{array}{l}\text { Czereśnie } \\
\text { Sour cherries }\end{array}$ & $\begin{array}{c}1 \\
(0,4)\end{array}$ & $\begin{array}{c}\text { cypermethrin } \\
\text { captan }\end{array}$ & $\begin{array}{l}1 \\
1 \\
\end{array}$ & $\begin{array}{l}100 \\
100 \\
\end{array}$ & $\begin{array}{c}0,070 \\
0,350^{1} \\
\end{array}$ & $\begin{array}{l}- \\
- \\
\end{array}$ & $\begin{array}{l}2 \\
5 \\
\end{array}$ \\
\hline $\begin{array}{l}\text { Gruszki } \\
\text { Pears }\end{array}$ & $\begin{array}{c}10 \\
(3,8)\end{array}$ & $\begin{array}{c}\text { acetamiprid } \\
\text { boscalid } \\
\text { cyprodinil } \\
\text { dithiocarbamates } \\
\text { fludioxonil } \\
\text { flusilazole } \\
\text { captan } \\
\text { pirimicarb } \\
\text { thiacloprid } \\
\end{array}$ & $\begin{array}{l}2 \\
2 \\
1 \\
4 \\
1 \\
1 \\
4 \\
1 \\
2 \\
\end{array}$ & $\begin{array}{l}20 \\
20 \\
10 \\
40 \\
10 \\
10 \\
40 \\
10 \\
20 \\
\end{array}$ & $\begin{array}{l}0,010 \\
0,010 \\
0,750 \\
0,080 \\
0,210 \\
0,020 \\
0,020 \\
0,020 \\
0,020 \\
\end{array}$ & $\begin{array}{c}0,020 \\
0,020 \\
- \\
0,230 \\
- \\
- \\
0,140 \\
- \\
0,040 \\
\end{array}$ & $\begin{array}{c}0,8 \\
2 \\
1 \\
5 \\
5 \\
0,02 \\
3 \\
2 \\
0,3 \\
\end{array}$ \\
\hline $\begin{array}{l}\text { Jabłka } \\
\text { Apples }\end{array}$ & $\begin{array}{c}42 \\
(16,2)\end{array}$ & $\begin{array}{c}\text { acetamiprid } \\
\text { boscalid } \\
\text { chlorpyrifos } \\
\text { cypermethrin } \\
\text { cyprodinil } \\
\text { dithiocarbamates } \\
\text { fenazaquin } \\
\text { flonicamid } \\
\text { fludioxonil } \\
\text { flusilazole } \\
\text { indoxacarb } \\
\text { captan } \\
\text { lambda-cyhalothrin } \\
\text { pyrimethanil } \\
\text { pirimicarb } \\
\text { spirodiclofen } \\
\text { tebuconazole } \\
\text { thiacloprid } \\
\text { trifloxystrobin } \\
\end{array}$ & $\begin{array}{c}7 \\
4 \\
4 \\
3 \\
2 \\
8 \\
3 \\
1 \\
1 \\
1 \\
1 \\
16 \\
1 \\
4 \\
1 \\
6 \\
4 \\
2 \\
2 \\
\end{array}$ & $\begin{array}{c}17 \\
10 \\
10 \\
7 \\
5 \\
19 \\
7 \\
2 \\
2 \\
2 \\
2 \\
38 \\
2 \\
10 \\
2 \\
14 \\
10 \\
5 \\
5 \\
\end{array}$ & $\begin{array}{l}0,010 \\
0,020 \\
0,030 \\
0,040 \\
0,050 \\
0,050 \\
0,040 \\
0,020 \\
0,030 \\
0,010 \\
0,040 \\
0,010 \\
0,030 \\
0,070 \\
0,020 \\
0,010 \\
0,010 \\
0,020 \\
0,010 \\
\end{array}$ & $\begin{array}{c}0,040 \\
0,250 \\
0,270 \\
0,060 \\
0,150 \\
0,530 \\
0,110^{1} \\
- \\
- \\
- \\
- \\
0,370 \\
- \\
0,160 \\
- \\
0,060 \\
0,090 \\
0,040 \\
0,020 \\
\end{array}$ & $\begin{array}{c}0,8 \\
2 \\
0,5 \\
1 \\
1 \\
5 \\
0,1 \\
0,2 \\
5 \\
0,02 \\
0,5 \\
3 \\
0,1 \\
5 \\
2 \\
0,8 \\
1 \\
0,3 \\
0,5 \\
\end{array}$ \\
\hline $\begin{array}{l}\text { Kapusta } \\
\text { pekińska } \\
\text { Chinese } \\
\text { cabbage }\end{array}$ & $\begin{array}{c}10 \\
(3,8)\end{array}$ & $\begin{array}{c}\text { azoxystrobin } \\
\text { chlorpyrifos } \\
\text { cypermethrin } \\
\text { dimethoate } \\
\text { iprodione } \\
\text { pyrimethanil } \\
\text { tebuconazole } \\
\end{array}$ & $\begin{array}{l}4 \\
4 \\
1 \\
1 \\
1 \\
1 \\
1\end{array}$ & $\begin{array}{c}40 \\
40 \\
100 \\
100 \\
100 \\
100 \\
100 \\
\end{array}$ & $\begin{array}{l}0,020 \\
0,030 \\
0,210 \\
0,080 \\
0,040 \\
0,110 \\
0,070^{1} \\
\end{array}$ & $\begin{array}{l}0,040 \\
0,120 \\
- \\
- \\
- \\
- \\
- \\
\end{array}$ & $\begin{array}{c}5 \\
0,5 \\
1 \\
0,02 \\
5 \\
0,05 \\
1 \\
\end{array}$ \\
\hline $\begin{array}{l}\text { Maliny } \\
\text { Raspberries }\end{array}$ & $\begin{array}{c}4 \\
(1,5)\end{array}$ & $\begin{array}{l}\text { chlorpyrifos } \\
\text { pyrimethanil } \\
\text { thiacloprid } \\
\end{array}$ & $\begin{array}{l}1 \\
2 \\
2 \\
\end{array}$ & $\begin{array}{l}25 \\
50 \\
50 \\
\end{array}$ & $\begin{array}{l}0,010 \\
0,320 \\
0,050 \\
\end{array}$ & $\begin{array}{c}- \\
2,400 \\
- \\
\end{array}$ & $\begin{array}{c}0,5 \\
10 \\
3 \\
\end{array}$ \\
\hline $\begin{array}{l}\text { Marchew } \\
\text { Carrots }\end{array}$ & $\begin{array}{c}11 \\
(4,2)\end{array}$ & $\begin{array}{c}\text { azoxystrobin } \\
\text { boscalid } \\
\text { chlorpyrifos } \\
\text { chlorpyrifos ethyl } \\
\end{array}$ & $\begin{array}{l}2 \\
4 \\
6 \\
1\end{array}$ & $\begin{array}{c}18 \\
36 \\
55 \\
9\end{array}$ & $\begin{array}{l}0,030 \\
0,020 \\
0,010 \\
0,050 \\
\end{array}$ & $\begin{array}{c}0,040 \\
0,350 \\
0,180 \\
- \\
\end{array}$ & $\begin{array}{c}1 \\
2 \\
0,1 \\
0,1 \\
\end{array}$ \\
\hline $\begin{array}{l}\text { Ogórki } \\
\text { Cucumbers }\end{array}$ & $\begin{array}{c}10 \\
(3,8)\end{array}$ & $\begin{array}{c}\text { azoxystrobin } \\
\text { chlorothalonil } \\
\text { dithiocarbamates }\end{array}$ & $\begin{array}{l}1 \\
1 \\
4 \\
\end{array}$ & $\begin{array}{l}10 \\
10 \\
40 \\
\end{array}$ & $\begin{array}{c}0,060^{1} \\
0,350 \\
0,050 \\
\end{array}$ & $\begin{array}{c}- \\
- \\
0,190 \\
\end{array}$ & $\begin{array}{l}1 \\
1 \\
2 \\
\end{array}$ \\
\hline $\begin{array}{l}\text { Papryka } \\
\text { Peppers }\end{array}$ & $\begin{array}{c}8 \\
(3,1)\end{array}$ & $\begin{array}{c}\text { azoxystrobin } \\
\text { dithiocarbamates } \\
\text { tebufenpyrad }\end{array}$ & $\begin{array}{l}1 \\
1 \\
1\end{array}$ & $\begin{array}{l}13 \\
13 \\
13 \\
\end{array}$ & $\begin{array}{l}0,290 \\
0,060 \\
0,040\end{array}$ & $\begin{array}{l}- \\
- \\
-\end{array}$ & $\begin{array}{c}3 \\
5 \\
0,5 \\
\end{array}$ \\
\hline
\end{tabular}




\begin{tabular}{|c|c|c|c|c|c|c|c|}
\hline 1 & 2 & 3 & 4 & 5 & 6 & 7 & 8 \\
\hline $\begin{array}{l}\text { Pietruszka } \\
\text { Parsley root }\end{array}$ & $\begin{array}{c}5 \\
(1,9)\end{array}$ & $\begin{array}{l}\text { azoxystrobin } \\
\text { chlorpyrifos }\end{array}$ & $\begin{array}{l}1 \\
1\end{array}$ & $\begin{array}{l}20 \\
20\end{array}$ & $\begin{array}{c}0,050^{1} \\
0,010\end{array}$ & - & $\begin{array}{c}1 \\
0,05\end{array}$ \\
\hline $\begin{array}{l}\text { Porzeczki } \\
\text { Currants }\end{array}$ & $\begin{array}{c}38 \\
(14,6)\end{array}$ & $\begin{array}{l}\text { alpha-cypermethrin } \\
\text { boscalid } \\
\text { chlorpyrifos } \\
\text { chlorpyrifos ethyl } \\
\text { cypermethrin } \\
\text { cyprodinil } \\
\text { deltamethrin } \\
\text { difenoconazole } \\
\text { dithiocarbamates } \\
\text { fenazaquin } \\
\text { fludioxonil } \\
\text { flusilazole } \\
\text { lambda-cyhalothrin } \\
\text { thiacloprid } \\
\text { tolylfluanid }\end{array}$ & $\begin{array}{c}6 \\
5 \\
1 \\
1 \\
6 \\
2 \\
1 \\
17 \\
24 \\
3 \\
1 \\
2 \\
14 \\
19 \\
1\end{array}$ & $\begin{array}{c}16 \\
13 \\
3 \\
3 \\
16 \\
5 \\
3 \\
45 \\
63 \\
8 \\
3 \\
5 \\
37 \\
50 \\
3\end{array}$ & $\begin{array}{l}0,030 \\
0,020 \\
0,030 \\
0,020 \\
0,030 \\
0,040 \\
0,080 \\
0,030 \\
0,090 \\
0,030^{1,2} \\
0,050 \\
0,050 \\
0,020 \\
0,010 \\
0,030^{1,2}\end{array}$ & $\begin{array}{c}0,050 \\
3,310 \\
- \\
- \\
0,220^{2} \\
0,080 \\
- \\
0,430^{2} \\
0,440 \\
0,190 \\
- \\
0,080^{1,2} \\
0,120 \\
0,810 \\
-\end{array}$ & $\begin{array}{c}0,05 \\
10 \\
1 \\
1 \\
0,05 \\
5 \\
0,5 \\
0,2 \\
5 \\
0,01 \\
3 \\
0,02 \\
0,2 \\
1 \\
0,02\end{array}$ \\
\hline $\begin{array}{l}\text { Pomidory } \\
\text { Tomatoes }\end{array}$ & $\begin{array}{c}17 \\
(6,5)\end{array}$ & $\begin{array}{l}\text { azoxystrobin } \\
\text { boscalid } \\
\text { chlorothalonil } \\
\text { dithiocarbamates } \\
\text { famoxadone } \\
\text { iprodione }\end{array}$ & $\begin{array}{l}2 \\
2 \\
2 \\
7 \\
1 \\
1\end{array}$ & $\begin{array}{l}12 \\
12 \\
12 \\
41 \\
6 \\
6\end{array}$ & $\begin{array}{l}0,040 \\
0,030 \\
0,010 \\
0,050 \\
0,170 \\
0,060\end{array}$ & $\begin{array}{l}0,060 \\
0,100 \\
0,550 \\
0,420 \\
- \\
-\end{array}$ & $\begin{array}{l}3 \\
3 \\
2 \\
3 \\
1 \\
5\end{array}$ \\
\hline $\begin{array}{l}\text { Rzepak } \\
\text { Oilseed rape }\end{array}$ & $\begin{array}{c}14 \\
(5,4)\end{array}$ & $\begin{array}{c}\text { tebuconazole } \\
\text { pirimiphos-methyl }\end{array}$ & $\begin{array}{l}1 \\
1\end{array}$ & $\begin{array}{l}7 \\
7\end{array}$ & $\begin{array}{l}0,060 \\
0,240^{2}\end{array}$ & $\begin{array}{l}- \\
-\end{array}$ & $\begin{array}{c}0,5 \\
0,05\end{array}$ \\
\hline $\begin{array}{l}\text { Rzodkiewka } \\
\text { Radishes }\end{array}$ & $\begin{array}{c}3 \\
(1,2)\end{array}$ & phosalone & 1 & 33 & 0,020 & - & 0,01 \\
\hline $\begin{array}{l}\text { Sałata } \\
\text { Lettuce }\end{array}$ & $\begin{array}{c}5 \\
(1,9)\end{array}$ & azoxystrobin & 3 & 60 & 0,100 & 1,550 & 15 \\
\hline $\begin{array}{l}\text { Seler } \\
\text { Celery }\end{array}$ & $\begin{array}{c}7 \\
(2,7) \\
\end{array}$ & $\begin{array}{l}\text { epoxiconazole } \\
\text { chlorpyrifos }\end{array}$ & $\begin{array}{l}2 \\
1\end{array}$ & $\begin{array}{l}29 \\
14\end{array}$ & $\begin{array}{l}0,010 \\
0,040\end{array}$ & $\begin{array}{c}0,030 \\
-\end{array}$ & $\begin{array}{l}0,05 \\
0,05\end{array}$ \\
\hline $\begin{array}{l}\text { Śliwki } \\
\text { Plums }\end{array}$ & $\begin{array}{c}7 \\
(2,7)\end{array}$ & $\begin{array}{c}\text { dithiocarbamates } \\
\text { tebuconazole }\end{array}$ & $\begin{array}{l}1 \\
3\end{array}$ & $\begin{array}{l}14 \\
43\end{array}$ & $\begin{array}{l}0,290 \\
0,070\end{array}$ & 0,210 & $\begin{array}{l}2 \\
1\end{array}$ \\
\hline $\begin{array}{l}\text { Truskawki } \\
\text { Strawberries }\end{array}$ & $\begin{array}{c}10 \\
(3,8)\end{array}$ & $\begin{array}{c}\text { boscalid } \\
\text { cyprodinil } \\
\text { dithiocarbamates } \\
\text { fludioxonil } \\
\text { folpet } \\
\text { pyrimethanil }\end{array}$ & $\begin{array}{l}3 \\
4 \\
3 \\
2 \\
1 \\
1\end{array}$ & $\begin{array}{l}30 \\
40 \\
30 \\
20 \\
10 \\
10\end{array}$ & $\begin{array}{l}0,040 \\
0,010 \\
0,080 \\
0,020 \\
0,230 \\
0,080\end{array}$ & $\begin{array}{l}0,100 \\
0,120 \\
0,230 \\
0,030 \\
- \\
-\end{array}$ & $\begin{array}{c}10 \\
5 \\
10 \\
3 \\
3 \\
5\end{array}$ \\
\hline $\begin{array}{l}\text { Wiśnie } \\
\text { Sweet cherries }\end{array}$ & $\begin{array}{c}3 \\
(1,2)\end{array}$ & $\begin{array}{c}\text { boscalid } \\
\text { difenoconazole } \\
\text { captan }\end{array}$ & $\begin{array}{l}1 \\
1 \\
2\end{array}$ & $\begin{array}{l}33 \\
33 \\
67 \\
\end{array}$ & $\begin{array}{l}0,010 \\
0,070 \\
0,420\end{array}$ & $\begin{array}{c}- \\
- \\
0,740\end{array}$ & $\begin{array}{c}4 \\
0,3 \\
5\end{array}$ \\
\hline
\end{tabular}

*NDP - najwyższe dopuszczalne poziomy pozostałości - MRLs - Maximum Residue Levels

**Zgodnie z EU Pesticides Database - Products as in Reg. (EU) No 212/2013

According to EU Pesticides Database - Products as in Reg. (EU) No 212/2013

${ }^{1}$ substancja, której stosowanie nie jest zalecane w danej uprawie - application of the substance is not recommended for that crop

${ }^{2}$ substancja, której pozostałość przekroczyła najwyższy dopuszczalny poziom (NDP) - the substance which residue level exceeded the maximum residue limit (MRL)

W przypadku przekroczeń najwyższych dopuszczalnych poziomów (NDP) lub zastosowania preparatu niezgodnego z zaleceniami przygotowano powiadomienia w ramach systemu RASFF. W okresie badawczym spośród 17 powiadomień najwięcej dotyczyło zastosowania preparatu niezgodnie $\mathrm{z}$ etykietą - 13, w 4 przypadkach stwierdzono przekroczenia wartości NDP, w 8 zaś jednoczesne przekroczenie NDP i zastosowanie preparatu niezgodnie z etykietą (Ustawa 2004). Największa liczba powiadomień dotyczyła owoców $(76,5 \%)$, w tym próbek porzeczek $(47,1 \%)$. Dane literaturowe i uzyskane wyniki potwierdzają, iż owoce są grupą upraw, w której pro- ducenci najczęściej stosują chemiczne ś.o.r. (Łozowicka i wsp. 2011, 2012, 2013; Nowacka i wsp. 2009, 2010, 2011, 2012). Sięganie przez producentów po środki niezalecane jest związane głównie z brakiem właściwych preparatów zarejestrowanych do ochrony danej uprawy (Szpyrka i wsp. 2012). Powiadomienia dotyczące warzyw stanowiły $17,6 \%$, natomiast zbóż i roślin oleistych 5,9\%.

Wszczęcie procedury RASFF stanowi podstawę do oszacowania narażenia zdrowia konsumentów. Jednym z najistotniejszych elementów oceny ryzyka jest odniesienie pobranego spożycia produktu zawierającego podwyższony poziom pozostałości pestycydu do ARfD wyzna- 
czonej dla tego pestycydu. Za dopuszczalne, nie stwarzające zagrożeń dla zdrowia przyjmuje się wartości oszacowanego narażenia konsumentów na pozostałości ś.o.r. nie przekraczające $100 \%$ wartości ARfD (Scientific Report of EFSA 2013). Oszacowane ryzyko ostre w przypadku kaptanu w czereśniach (117\% ARfD), difenokonazolu w agreście (169\% ARfD) i w czarnej porzeczce (269\% ARfD), fenazachiny w czarnej porzeczce (190\% ARfD) i w jabłkach (110\% ARfD), cypermetryny w czarnej porzeczce (110\% ARfD), flusilazolu w czarnej porzeczce (1600\% ARfD), pirymifosu metylowego w rzepaku ozimym (160\% ARfD) oraz tebukonazolu w kapuście pekińskiej (233\% ARfD), wykazało nieakceptowane zagrożenie dla zdrowia.

W 2013 roku, w Polsce północno-wschodniej, w porównaniu do lat ubiegłych, odnotowano najwyższy odsetek próbek płodów rolnych zanieczyszczonych pozostałościami ś.o.r. - 50,8\%. W 2008 roku wyniósł on 45,5\%, w 2009 r. $-38,3 \%$, w 2010 r. $-28,3 \%$, w 2011 r. $-33,1 \%$, w 2012 r. - 18,8\% (Łozowicka i wsp. 2012, 2013).

W celu porównania stopnia zanieczyszczenia pestycydami płodów rolnych z północno-wschodniej Polski, najbardziej miarodajnym wydaje się odniesienie wyników badań do monitoringu krajowego, prowadzonego w laboratoriach o podobnych możliwościach analitycznych i według jednakowych programów badań. W 2013 roku, w krajowej produkcji pierwotnej, w 32,4\% ogółu analizowanych próbek stwierdzono obecność pozostałości ś.o.r. Porównywalnie, jak w województwie północno-wschodnim odnotowano, aż 46,5\% próbek owoców zawierających pozostałości ś.o.r. (Nowacka i wsp. 2013).

\section{Podsumowanie / Summation}

1. Oceniono, iż owoce wnoszą największy odsetek próbek z pozostałościami $(74,4 \%)$, warzywa dwukrotnie mniejszy - 37,4\%, natomiast zboża i rośliny oleiste poniżej $10 \%$. Podobną tendencję zaobserwowano również w latach ubiegłych. Potwierdza to fakt, iż owoce należą do upraw poddawanych licznym zabiegom chemicznym, co z kolei przyczynia się do występowania w nich największego odsetka próbek z pozostałościami.

2. Najczęściej wykrywaną grupą pestycydów były fungicydy. Można stąd wnioskować, iż właśnie ta grupa może mieć decydujące znaczenie w zanieczyszczaniu żywności w Polsce północno-wschodniej. Jednakże fungicydy $w$ przeciwieństwie do insektycydów czy innych grup pestycydów, są mniej szkodliwe dla środowiska, co ma związek ze stosunkowo niską toksycznością czy szybkim procesem rozkładu.

3. W stosunku do lat ubiegłych, w 2013 roku stwierdzono wyższy odsetek próbek wielopozostałościowych, co w aspekcie bezpieczeństwa żywności niesie większe ryzyko narażenia zdrowia konsumentów.

4. Powiadomienia informacyjne przygotowane w ramach sytemu RASFF dotyczyły głównie pozostałości ś.o.r. w próbkach owoców, wśród których największy odsetek niezgodności odnotowano dla porzeczek.

5. W oparciu o wyniki szacowania narażenia ostrego zdrowia konsumentów przeprowadzonego dla dzieci stwierdzono, większą niż w latach ubiegłych liczbę próbek, która stanowi nieakceptowane zagrożenie dla zdrowia.

6. W niniejszych badaniach wykazano, że producenci stosują niedopuszczone do obrotu ś.o.r., bądź nie stosują się do zaleceń stosowania preparatów zgodnie $\mathrm{z}$ etykietą. Dlatego należy kontynuować badania na obecność pozostałości ś.o.r. stosując metody analityczne obejmujące jak najszerszą liczbę s.cz.

7. Na podstawie uzyskanych wyników oraz w oparciu o wyniki porównawcze uzyskiwane dla innych rejonów Polski, należy powiadomić służby rolne o obserwowanych tendencjach, celem podjęcia działań, mających poprawić zaistniałą sytuację obserwowanego wzrostu ilości produktów rolnych zawierających pozostałości ś.o.r.

\section{Literatura / References}

Chmiel Z. 1979. Spektrofotometryczne oznaczanie śladowych pozostałości dwutiokarbaminianów w materiale roślinnym. Chem. Anal. $505-511$

Łozowicka B. 2010. Studium nad pozostałościami środków ochrony roślin w płodach rolnych północno-wschodniej Polski. Rozpr. Nauk. Inst. Ochr. Roślin - PIB 21, 177 ss.

Łozowicka B., Kaczyński P. 2009. Determination of carbendazim, linuron and glyphosate residues by HPLC method. Pol. J. Environ. Stud. 18 (2B): 100-104.

Łozowicka B., Hrynko I., Jankowska M., Rutkowska E., Kaczyński P., Janowicz T. 2011. System wczesnego ostrzegania o niebezpiecznej żywności i paszach (RASFF) w odniesieniu do pozostałości środków ochrony roślin w płodach rolnych północnowschodniej Polski. [Rapid alert system for food and feed (RASFF) for pesticide residues in crops from north-eastern Poland]. Prog. Plant Prot./Post. Ochr. Roślin 51 (2): 990-995.

Łozowicka B., Hrynko I., Rutkowska E., Jankowska M., Kaczyński P., Janowicz T. 2012. Pozostałości środków ochrony roślin w owocach i warzywach z północno-wschodniej Polski (2008-2011). [Pesticide residues in fruit and vegetables from north-eastern Poland (2008-2011)]. Prog. Plant Prot./Post. Ochr. Roślin 52 (2): 423-430.

Łozowicka B., Hrynko I., Rutkowska E., Jankowska M., Kaczyński P. 2013. Kontrola urzędowa pozostałości środków ochrony roślin w płodach rolnych północno-wschodniej Polski (2012). [Official control of pesticide residues in crops (2012)]. Prog. Plant Prot./Post. Ochr. Roślin 53 (3): 571-575.

Nowacka A., Gnusowski B., Walorczyk S., Drożdżyński D., Wójcik A., Raczkowski M., Hołodyńska A., Barylska E., Ziółkowski A., Chmielewska E., Rzeszutko U., Giza I., Łozowicka B., Kaczyński P., Rutkowska E., Szpyrka E., Rupar J., Rogozińska K., Machowska A., Słowik-Borowiec M., Kuźmenko A., Szala J. 2009. Pozostałości środków ochrony roślin w płodach rolnych (rok 2008). [Pesticide residues in crops (2008)]. Prog. Plant Prot./Post. Ochr. Roślin 49 (4): 1903-1917. 
Nowacka A., Gnusowski B., Walorczyk S., Drożdżyński D., Wójcik A., Raczkowski M., Hołodyńska A., Barylska E., Ziółkowski A., Chmielewska E., Rzeszutko U., Giza I., Jurys J., Łozowicka B., Kaczyński P., Rutkowska E., Jankowska M., Szpyrka E., Rupar J., Rogozińska K., Kurdziel A., Machowska A., Słowik-Borowiec M., Kuźmenko A., Szala J., Sadło S. 2010. Pozostałości środków ochrony roślin w płodach rolnych (rok 2009). [Pesticide residues in agricultural products (2009)]. Prog. Plant Prot./Post. Ochr. Roślin 50 (4): 1947-1962.

Nowacka A., Gnusowski B., Walorczyk S., Drożdżyński D., Raczkowski M., Hołodyńska A., Frąckowiak D., Wójcik A., Ziółkowski A., Rzeszutko U., Domańska I., Jurys J., Łozowicka B., Kaczyński P., Rutkowska E., Jankowska M., Hrynko I., Szpyrka E., Rupar J., Rogozińska K., Kurdziel A., Słowik-Borowiec M., Michel M., Kuźmenko A., Szala J. 2011. Pozostałości środków ochrony roślin w płodach rolnych (rok 2010). [Pesticide residues in polish crops (2010)]. Prog. Plant Prot./Post. Ochr. Roślin 51 (4): 1723-1738.

Nowacka A., Gnusowski B., Walorczyk S., Drożdżyński D., Raczkowski M., Hołodyńska A., Frąckowiak D., Wójcik A., Ziółkowski A., Przewoźniak M., Swoboda W., Rzeszutko U., Domańska I., Jurys J., Łozowicka B., Kaczyński P., Rutkowska E., Jankowska M., Hrynko I., Szpyrka E., Rupar J., Rogozińska K., Kurdziel A., Słowik-Borowiec M., Szala J., Szponik M., Michel M. 2012. Pozostałości środków ochrony roślin w płodach rolnych (rok 2011). [Pesticide residues in Polish crops (2011)]. Prog. Plant Prot./Post. Ochr. Roślin 52 (4): 1106-1116.

Nowacka A., Frąckowiak D., Gnusowski B. 2013. Badanie pozostałości środków ochrony roślin w płodach rolnych. Sprawozdanie za rok 2013. Inst. Ochr. Roślin - PIB, 160 ss.

PSD 2006. New intake calculation models for consumer intake assessments. http://psd08.pesticides.gov.uk/print.asp?id=1687\&link= $\% 2$ Fuploadedfiles\%2FChronic\%5Fintake\%5Fguidance\%5Fver1\%2Epdf [Accessed: 14.01.2014].

SANCO/12495/2011. 2011. Metod Validation and Quality Control Procedures for Pesticide Residues Analysis in Food and Feed, 40 pp.

Scientific Report of EFSA. 2013. The 2010 European Union report on pesticide residues in food. EFSA J. 11 (3): 30-31, 209 pp. DOI:10.2903/j.efsa.2013.3130.

Szpyrka E., Kurdziel A., Grzegorzak M., Rupar J., Słowik-Borowiec M., Matyaszek A. 2012. Pozostałości środków ochrony roślin w płodach rolnych z terenu południowo-wschodniej Polski. [Pesticide residues in crops from the south-eastern region of Poland]. Prog. Plant Prot./Post. Ochr. Roślin 52 (1): 149-152.

Szpyrka E., Kurdziel A., Matyaszek A., Podbielska M., Rupar J., Słowik-Borowiec M. 2013. Pozostałości środków ochrony roślin w płodach rolnych z terenu południowo-wschodniej Polski. [Pesticide residues in crops from the south-eastern region of Poland]. Prog. Plant Prot./Post. Ochr. Roślin 53 (2): 402-406.

Ustawa z dnia 18 grudnia 2003 r. o ochronie roślin. 2004. (Dz. U. z dnia 27 stycznia 2004 r. Nr 11, poz. 94 z późn. zm). http://isap.sejm.gov.pl/DetailsServlet?id=WDU20040110094 [dostęp: 08.01.2014].

Ustawa z dnia 25 sierpnia 2006 r. o bezpieczeństwie żywności i żywienia. (Dz. U. Nr 171, poz. 1225, z późn. zm.). http://isap.sejm.gov.pl/DetailsServlet?id=WDU20061711225 [dostęp: 08.01.2014].

Rozporządzenie WE 2005. Rozporządzenie (WE) nr 396/2005 Parlamentu Europejskiego i Rady Europy z dnia 23 lutego 2005 roku $\mathrm{z}$ późn. zm. w sprawie najwyższych dopuszczalnych poziomów pozostałości pestycydów w żywności i paszy pochodzenia roślinnego i zwierzęcego oraz na ich powierzchni, zmieniające dyrektywę Rady 91/414/EWG (Dz. Urz. L 70, str. 1 z 16.03.2005). 